\title{
MATERNIDAD TARDÍA: OPCIÓN LEGÍTIMA, FRUTO DE DERECHOS CIVILES Y CONSTITUCIONALES. DEBATE JURÍDICO E INTROMISIÓN ÉTICA EN LAS REDES SOCIALES.
}

\author{
Patricia Craviotto Valle ${ }^{1}$
}

\section{RESUMEN}

El presente artículo tiene como objetivo animar al lector -interesado en los aspectos jurídicos y biotecnológicos respecto a la maternidad tardía-, a realizar una profunda reflexión ética y jurídica al respecto. En el mundo globalizado en el que vivimos, las redes sociales y los medios de comunicación -cada vez más interactivos-, nos obliga a cuidar con especial mimo y protección las nuevas situaciones nacidas de los avances tecnológicos.

Sin el ánimo ni pretensión de convencer o modificar posturas personales -e incluso profesionales-, la redacción de este escrito se fundamenta en la preocupación que nace en la autora de la misma, al advertir una continua falta de reflexión generalizada respecto asuntos concernientes a derechos fundamentales de la persona. Derechos o posibilidades lícitas que nacen de la libertad personal, y que puede ser tergiversada por las redes sociales, influyendo de manera errónea en el conjunto global de las actuales sociedades: muy especialmente en la sociedad española.

\section{SUMMARY}

The objective of this article is to encourage the reader -interested in legal and biotechnological aspects regarding late motherhood- to carry out a deep ethical and legal reflection in this regard. In the globalized world in which we live, social networks and the media -increasingly interactive- oblige us to take special care of and protect the new situations born of technological advances.

\footnotetext{
${ }^{1}$ Departamento Derecho Civil e Internacional Privado. Facultad de Derecho - Universidad de Sevilla Mediadora Civil y Mercantil - Inscrita en Registro Ministerio de Justicia y Registro Mediadores de Familia: Junta de Andalucía ( ${ }^{\circ}$ 1587)
} 
Without the spirit or pretense of convincing or modifying personal positions -and even professionals-, the writing of this writing is based on the concern that arises in the author of the same, when warning a continuous lack of generalized reflection on matters concerning fundamental rights of the person. Rights or legal possibilities that arise from personal freedom, and that can be distorted by social networks, influencing in a wrong way in the global set of current societies: very especially in the Spanish society.

\section{PALABRAS CLAVE / KEY WORDS}

Maternidad, edad, derecho, biotecnología, redes.

Motherhood, age, law, biotechnology, networks.

Iniciar un artículo cuyos requisitos se acerquen a los exigidos por la Revista IUS ET SCIENTIA, no es labor sencilla. Máxime cuando nos encontramos insertos en una sociedad cuyos cambios se aceleran exponencialmente, impidiendo mantener un ritmo equitativo entre los avances sociales y la redacción de escritos de investigación.

Debo sentirme orgullosa de lo que a continuación se redacta, puesto que no solo se trata de un trabajo no publicado hasta este momento, sino que además no ha sido presentado a ningún otro tipo de publicaciones -en cualquier tipo de formato-.

La bioética, el bioderecho, las nuevas tecnologías y los derechos humanos, son las bases que motivan la existencia de esta Revista ${ }^{2}$. Más no deja por ello de estar ligada directamente al derecho Civil, marco regulador de las relaciones entre personas. Igualmente no es ajena al derecho Administrativo, toda vez que las personas hemos de interrelacionarnos con administraciones públicas que gestionan de una manera $\mathrm{u}$ otra, situaciones de la persona cuyo interés puede ser público -a pesar de su inminente raíz privada-.

\footnotetext{
${ }^{2}$ IUS ET SCENTIA. Volumen 3, № 2. (ISSN 2444-8478)
} 
El título de este artículo pretende abordar una situación muy actual que comienza a ocupar un respetable espacio social, cuya repercusión jurídica se pone en entredicho: ¿Debemos regular al respecto? ¿Hemos de continuar como hasta ahora, sin regular ciertos aspectos referentes al "derecho" a la maternidad? ¿Debe existir un límite de edad en la mujer para ser madre? ¿Es jurídicamente viable en nuestro ordenamiento español? ¿Cuáles son los beneficios y perjuicios que afectan a bienes jurídicos dignos de protección, como pueden ser los hijos nacidos de madres de edad avanzada? El debate social se ha abierto a raíz de las aplicaciones de la biotecnología en este campo, y no deja indiferente a nadie.

Dado que vivimos en una sociedad globalizada y supra conectada mediante las redes sociales, coincidiremos en la siguiente afirmación: ojos que no ven, corazón que no siente.

¿Cuántos casos poco usuales se han ido produciendo en la sociedad sin que esta sea consciente de los mismos, o lo han sido a escalas ínfimas? Casos relacionados con los derechos de la persona -específicos y curiosos cuando menos-, que sin regulación normativa alguna, nunca generaron la necesidad de ello. Coincidiremos en que ha ocurrido a lo largo de toda nuestra historia. No se puede regular lo que se desconoce. No se regula lo que no crea conflicto per se.

Algunos médicos ${ }^{3}$ han investigado acerca de enfermedades que han existido durante toda la vida -como es el caso del alzhéimer-, y sin embargo no han sido diagnosticadas hasta hace muy poco tiempo. La pérdida de memoria progresiva, la disminución de la función motora, etc., hizo que neurocientíficos como Patrick McGeer y su equipo estudiasen historias médicas antiguas en doce mil pacientes, los cuales habían tomado altas dosis de antiinflamatorios -aspirina-, en el intento de mitigar dolores relacionados con la artritis. Comprobaron que tenían siete veces menos probabilidades de ser diagnosticados de alzhéimer, respecto aquellos que no la habían tomado. El estudio se realizó de nuevo en

\footnotetext{
${ }^{3}$ Es el caso del Doctor Chopra, el cual insiste en aquellos hechos médicos y mitos que todos deberíamos conocer.
} 
Holanda en 2001, tratando a siete mil pacientes con ibuprofeno o naproxeno para el dolor de artritis. De nuevo llamó la atención que había en estos pacientes una probabilidad significativa de no contraer alzhéimer, frente a otra población no tratada.

El Dr. Steven Vlad ${ }^{4}$-Universidad de Medicina de Boston-, examinó a casi cincuenta mil veteranos de guerra con alzhéimer y otros veinte mil de aproximadamente la misma edad -74 años-, que no padecían esta enfermedad. La conclusión fue que los pacientes que habían consumido antiinflamatorios -no esteroides- durante más de cinco años, tenían un probabilidad de un 24 por ciento menos de desarrollar síntomas de alzhéimer.

Puede afirmarse que a pesar de que la enfermedad fue identificada en 1906 por Aloysius Alzheimer $^{5}$-a raíz del estudio de un paciente que trató en 1901-, este hecho y los estudios posteriores confirman que efectivamente es una enfermedad que acompaña al ser humano desde hace siglos, si no milenios.

De hecho un grupo de investigadores colaboraron en 2008 -norteamericanos y alemanes, analizando una situación curiosa que ocurría en India: menos de un 1 por ciento de la población mayor de 65 años, estaba diagnosticada con alzhéimer. Al parecer las dietas ricas en determinadas sustancias -en este caso un componente del curry-, reaccionan en el ser humano como un elemento natural que evita ciertas dolencias. Volvemos a indicarlo de otra manera: hay enfermedades que sin ser diagnosticadas hasta hace relativamente poco tiempo, estuvieron siempre presente en la sociedad.

Sin embargo -y este es el punto de reflexión que conecta con nuestro artículo-, hasta hace muy poco tiempo no tuvimos información tan completa respecto al alzhéimer. La

\footnotetext{
${ }^{4}$ Steven Vlad es un doctor especializado en reumatología, formado en la Universidad de Iowa, en el reconocido Boston Medical Center, y cuyo doctorado finalizó en la Universidad de Boston. Su línea de investigación se basa en la afectación adversa de medicamentos que son utilizados en el tratamiento de enfermedades reumatológicas.

${ }^{5}$ Aloysisu Alzehimer (1864-1915), fue un psiquiatra y neurólogo alemán que identificó por vez primera los síntomas de la enfermedad que más tarde llevaría su nombre. Observando a un paciente en 1901 y tras examinar su cerebro al morir, Alzheimer publicó en 1906 lo que descubrió.
} 
sociedad no solo desconocía los orígenes de la misma sino que no entendía estas situaciones personales como una enfermedad: era una cuestión de naturaleza. Cuántas veces hemos escuchado en ambientes familiares afirmaciones como la abuela empieza a chochear, o el abuelo comienza a decir tonterías.... En muchos de estos casos -no diagnosticados en su día-, nos encontrábamos ante un claro ejemplo de inicio de alzhéimer. Sin embargo no nos preocupábamos por ello pues no existía como tal esta enfermedad, y por tanto la necesidad de ampararla bajo regulación alguna.

Sin embargo en la actualidad existen dos leyes marco de sanidad, que apoyan a familiares y enfermos de Alzhéimer y otras demencias, como son la Ley 33/2011, de 4 de octubre, General de Salud Pública, y la Ley 16/2003, de 28 de mayo, de cohesión y calidad del Sistema Nacional de Salud. ¿Por qué hemos regulado situaciones de ayuda o apoyo a familiares en esta situación? Porque estas derivan en problemas sociales: conflictos dignos de amparo jurídico, ya que afectan a las personas enfermas directamente y a su entorno más cercano -familia, amigos, compañeros de trabajo,...-

Por analogía y continuando en la línea de la investigación respecto a las situaciones en las que las mujeres son madres a edades avanzadas, habríamos previamente que analizar similitudes y diferencias respecto al caso del alzhéimer, para adentrarnos seguidamente en encontrar o no sentido al hecho de regular la situación de estas madres tardías.

¿Qué similitudes tienen ambas circunstancias?

- Las dos son situaciones posibles a lo largo de la vida de las personas.

- El cuerpo sufre cambios importantes en ambas situaciones -pudiendo poner en riesgo la salud de la misma-.

- Tanto el alzhéimer como el embarazo son situaciones de la persona amparadas por el derecho, existiendo en la actualidad regulación jurídica respectivamente. 
- La enfermedad aparece a partir de un periodo de tiempo aproximado en la vida de los pacientes y el embarazo puede producirse -o no- también en una horquilla temporal de edades ${ }^{6}$.

- Ambas situaciones preocupan -por el riesgo a la salud que conllevan-, a organismos nacionales e internacionales ${ }^{7}$.

- Ambas situaciones tienen repercusiones jurídicas en el estado de la persona ${ }^{8}$.

- Alzhéimer y embarazo ${ }^{9}$, es compartido tanto en la especie humana como en la animal.

- Pueden producir cohesión social ${ }^{10}$, por el interés que despiertan.

- Ambas circunstancias pueden provocar rechazo social ${ }^{11}$.

¿Qué diferencias encontramos en sendas situaciones?

- El alzhéimer es una enfermedad, y la maternidad no lo es ${ }^{12}$.

- La enfermedad puede darse tanto en varones como en mujeres. En el embarazo, no: solo puede afectar a la población femenina.

\footnotetext{
${ }^{6}$ La OMS -Organización Mundial de la Salud-, nació el 7 de abril de 1948 y es una autoridad directiva y coordinadora en asuntos de sanidad internacional en el sistema de las Naciones Unidas -ONU-. Esta reconocida entidad se preocupa tanto de los niños como de las mujeres, especialmente en situaciones como el embarazo. En ningún caso limita o trata de limitar las edades en las que la mujer tiene capacidad para ser madre. http://www.who.int/es/

${ }^{7}$ Es el caso de la OMS, la UE, el Ministerio de Sanidad, Servicios Sociales e Igualdad -España-, Consejería de Salud de la Junta de Andalucía, etc.

${ }^{8}$ En el caso del enfermo de alzhéimer suele ir acompañada de una incapacidad de la persona, y el resultado final del embarazo, suele concluir con la filiación del hijo/a nacido/a.

${ }^{9}$ Cuando se hace referencia al embarazo de animales, con frecuencia se denomina preñez.

${ }^{10}$ Cohesión que se materializa en asociaciones de ayuda o apoyo, como la Fundación contra el Alzhéimer, o la Asociación Española de Pediatría -íntimamente ligada a la mujer embarazada y al nacimiento del hijo/a.

${ }^{11}$ En el caso del alzhéimer la sociedad no termina de aceptar esta enfermedad como parte de la vida, con los consecuentes conflictos que nacen alrededor de ella: abandono de familiares, repercusiones económicas negativas en el entorno - por la necesidad especial de cuidados-, etc. En el caso de los embarazos, no todos son deseados, no siempre se desarrollan biológicamente bien, existen políticas de natalidad-como la de China- que puede provocar el abandono de hijos recién nacidos, la decisión de abortar no es reconocida en todos los Estados, etc.

${ }^{12}$ El Comité de Aspectos Éticos de la Reproducción Humana y la Salud de las Mujeres de la Federación Internacional de Ginecología y Obstetricia (FIGO), en 2007definió embarazo como la parte del proceso de la reproducción humana que comienza con la implantación del conceptus en la mujer. Este se inicia en el momento de la nidación y culmina en el momento del parto.
} 
- El alzhéimer no es algo que se elija voluntariamente. El embarazo sí lo es ${ }^{13}$.

- Los cambios en el alzhéimer parten de la pérdida de tejido cerebral y la muerte progresiva de neuronas -degenerativo-, y los cambios ocurridos durante el embarazo, no son degenerativos. Todo lo contrario: se da vida a otro ser humano.

- El alzhéimer ha sido identificado por los científicos y trasladado al conocimiento general de la sociedad, desde hace poco más de un siglo. El embarazo es una fase biológica en los humanos, conocida desde el principio de los tiempos.

- La enfermedad del alzhéimer es a todas luces un problema digno de ser erradicado en el ser humano -prescindible a todas luces-, mientras que el embarazo es una cuestión imprescindible para la supervivencia de la especie humana.

Podríamos continuar añadiendo similitudes y diferencias llegando a la conclusión de que a pesar de ser situaciones completamente diferentes, tienen en común fundamentales consecuencias para el ser humano:

- Ambos son bienes jurídicos dignos de protección: a) la decisión de tener hijos es objeto de protección jurídica como se desprende -entre otros- del Preámbulo I de la LO 2/2010, de 3 de marzo, de salud sexual y reproductiva y de la interrupción voluntaria del embarazo ${ }^{14}$. De la misma manera el alzhéimer enmarca su protección en los artículos 10.1, 14, 15 y 17 de la $\mathrm{CE}^{15}$.

\footnotetext{
${ }^{13}$ No es motivo de este estudio analizar las situaciones en las que el embarazo ocurre sin el deseo de la mujer.

${ }^{14}$ El desarrollo de la sexualidad y la capacidad de procreación están directamente vinculados a la dignidad de la persona y al libre desarrollo de la personalidad y son objeto de protección a través de distintos derechos fundamentales, señaladamente, de aquellos que garantizan la integridad fisica y moral y la intimidad personal y familiar. La decisión de tener hijos y cuándo tenerlos constituye uno de los asuntos más intimos y personales que las personas afrontan a lo largo de sus vidas, que integra un ámbito esencial de la autodeterminación individual. Los poderes públicos están obligados a no interferir en ese tipo de decisiones, pero, también, deben establecer las condiciones para que se adopten de forma libre y responsable, poniendo al alcance de quienes lo precisen servicios de atención sanitaria, asesoramiento o información.

${ }^{15}$ Muy interesante es el Trabajo Fin de Máster -Máster en Protección Jurídica de las Personas y los Grupos Vulnerables- presentado por $\mathrm{D}^{\mathrm{a}}$ María Elvira Castaño Hernández y dirigido por $\mathrm{D}^{\mathrm{a}}$. Mónica Álvarez Fernández, en Oviedo, julio 2013. Bajo el título La Protección Jurídica de las Personas con Demencia tipo Alzhéimer, este trabajo desarrolla el encuadre jurídico donde debe considerarse la protección y la dignidad de aquellas personas que sufren esta enfermedad.
} 
- Las dos situaciones se originan por la propia naturaleza del ser humano y de su organismo. No puede entenderse ánimo antijurídico en la situación de querer ser madre, ni en la de sufrir una enfermedad degenerativa -que no se elige-.

- Biológica, médica, clínica, y tecnológicamente estamos preparados para afrontar modificaciones en ambas situaciones: así en el deseo de ser madre se ha avanzado mucho en tecnología reproductiva, y en el caso del alzhéimer se avanza en la precisión de su diagnóstico clínico, gracias a los avances sobre el mismo.

Partiendo de estas bases análogas estamos en disposición de profundizar en el asunto de la maternidad a edades tardías.

Tanto las sociedades mundiales en general como la española en particular, avanzan a pasos agigantados no solo respecto al uso y disfrute de las nuevas tecnologías y sus aplicaciones, sino respecto a su bienestar personal. El Estado de Bienestar es un concepto nacido en el siglo XIX que en principio hizo referencia a las reivindicaciones laborales respecto a las pésimas condiciones de los trabajadores.

Este Estado de Bienestar está muy vinculado al sistema económico en el que los Estados asumen responsabilidades y prestaciones de diversa índole, como es el caso de la sanidad o de la educación. Se procura que el destinatario -es decir el ciudadano-, no asuma los costes al respecto. En el sistema político y de gobierno español, dicho servicio es desarrollado por personal funcionario dependiente del Estado o de las diferentes Administraciones Autonómicas. Lógicamente este coste público asumido en pro de la ciudadanía, ha de ser presupuestado y aprobado por los diferentes entes responsables para tal fin, siendo el tipo de sociedad un factor muy importante a tener en cuenta.

En el caso de España, este estado de bienestar social ha sufrido una crisis derivada de la falta de recursos económicos. La presión fiscal, el elevado coste de los servicios, la disminución del consumo unido al aumento de peticiones o demandas sociales, ha provocado que dicho estado decrezca en cuanto a su calidad. Puede afirmarse que el 
estado de bienestar disfrutado antes de 2007, era mayor que el actual en nuestra sociedad. Tanto la cantidad de servicios ofertados al ciudadano como su calidad, han disminuido nítida y públicamente.

En el caso de la educación la importante disminución de presupuesto ha generado no solo falta de material común básico en colegios de primaria -como puede ser el papel higiénico ${ }^{16}$-, sino la falta de contratación de personal -como puede advertirse incluso en las Universidades-. Brevemente podríamos resumir que la falta de presupuesto en educación ha derivado -entre otras-, en las siguientes circunstancias:

- Imposibilidad de compra de material común. Las familias voluntariamente han tenido que cubrir este déficit para que asignaturas como tecnología o plástica, pudieran llevarse a cabo.

- Falta de personal docente con las consecuencias que ello conlleva: aumento de número de alumnos por clase en un mismo espacio; sobrecarga de trabajo en profesores; bajas laborales por estrés y depresión, etc.

- Disminución de becas y ayudas a la investigación.

- Falta de mantenimiento en los edificios, de materiales e instalaciones de los centros educativos ${ }^{17}$, etc.

Esta caída del estado de bienestar no es ajena al sector sanitario, dándose como circunstancias en los últimos años algunas de las siguientes situaciones:

- Tiempo de espera mayor en las asistencias médicas.

\footnotetext{
${ }^{16}$ La situación en los Colegios Públicos ha llegado al límite, no solo de desaparecer la renovación de equipos de aire acondicionado -imprescindibles para la docencia en lugares como Sevilla o Córdoba-, sino hasta productos básicos e imprescindibles como el jabón o el papel higiénico. Las AMPAs han sido las organizaciones sociales que han solucionado con su gestión -a través de donaciones de las familias-, este déficit de material necesario para centros educativos, especialmente los Centros de Educación Infantil y Primaria, dependientes de las diferentes Administraciones Autonómicas.

${ }^{17}$ Es el caso del CEIP Marie Curie de Sevilla. Este centro se inauguró en el curso académico 2009/2010, a falta de jardinería e instalaciones. Ello trajo como consecuencias que tanto los padres de los alumnos del centro como los docentes y el personal laboral que en él trabajaban en junio de 2017, realizasen una protesta popular y civil en búsqueda de soluciones para reducir la temperatura en aulas -con equipos de climatización que no existían-, y en los patios - con árboles o toldos que produjesen sombras y con ello el efecto pretendido. El lema era "queremos estudiar en aulas, no en saunas".
} 
- Disminución de coberturas sanitarias ${ }^{18}$.

- Falta de personal.

- Falta y/o disminución de equipos técnicos médicos: ambulancias, reposición de aparatos radiológicos, etc.

Todo ello acarreó como consecuencia matemática -en cifras económicas-, que las situaciones de necesidades básicas del ciudadano que no eran cubiertas por el Estado, habrían de cubrirse a partir de ahora de forma privada. Dicho de otra manera, el Estado de Bienestar Social ha disminuido y con él aumentó la necesidad de cubrir con recursos privados, lo que en principio cubría el gasto público.

La sociedad española es una de las más liberales del mundo. Recordaremos que fuimos uno de los primeros países del planeta ${ }^{19}$ en regular el matrimonio entre personas del mismo sexo ${ }^{20}$-concretamente en el año 2005-. Siendo así no es de extrañar que se hayan superado a escala social y jurídica, situaciones como la adopción dentro del matrimonio homosexual, o la posibilidad de adopción en las familias monoparentales -donde nunca existieron dos cónyuges-.

Estas nuevas situaciones familiares eran impensables hace breves décadas, donde la mujer no podía siquiera disponer de una propia cuenta bancaria sin que un varón titulara la misma. Hoy acogemos con total naturalidad las familias monoparentales nacidas tanto de la viudedad de uno de los cónyuges, como las madres y padres que unilateralmente optan por serlo sin necesidad de cónyuge alguno. De la misma manera consideramos la fecundación por medios tecnológicos, como algo normal y natural.

\footnotetext{
${ }^{18}$ Como ocurre en el caso de ginecología, donde algunas pruebas han dejado de realizarse, pasando al ámbito privado en exclusiva, como revisiones ginecológicas en la mujer. O reducción de coberturas en odontología, con el consecuente aumento de servicios de este tipo en el sector privado.

${ }^{19}$ España fue el cuarto Estado del mundo en aprobar el matrimonio entre homosexuales. El primero fue Holanda y el último -01.10.2017- ha sido Alemania.

${ }^{20}$ A través de la Ley 13/2005, de 1 de julio, por la que se modifica el Código Civil en materia de matrimonio -y uniones de hecho-, se sustituyó la expresión marido y mujer por la de cónyuges.
} 
En la actualidad más reciente ha nacido un debate socio-jurídico en relación a la maternidad subrogada, situación que muy probablemente se regulará en un futuro cercano a la vista de las exigencias de la sociedad española. Sin embargo ha nacido un debate más reciente aún- que nos impulsa a posicionarnos a uno u otro lado del mismo: la maternidad a edades superiores a los cincuenta años.

En el invierno de $2017^{21}$ saltó a los medios de comunicación una noticia que vislumbraba conflicto: el ingrediente perfecto para aumentar audiencias. Una mujer española de 64 años $^{22}$, de profesión médica y viuda, había dado a luz gemelos a los 62. Gracias a las redes sociales, en escasos segundos se convirtió en noticia de cabecera. Los magazines televisivos se hicieron eco de la información recibida e invitaron a esta señora a sentarse en sus platós. La señora tenía un hijo anterior -con alto grado de discapacidad-. La polémica estaba servida: mujer viuda, de 64 años, con hijo discapacitado, se insemina artificialmente y pare gemelos. ¿Está la sociedad española preparada para asumir esta situación? ¿Tiene algo que decir al respecto? ¿Puede oponerse jurídicamente a ella? Veamos la repercusión traída consigo.

Antes de analizar este caso concreto, hemos de advertir que la reciente madre se arrepintió en directo por haber claudicado a la invitación del programa televisivo, sintiendo haber sido una mera herramienta cuyo fin no era otro que el de criticar su egoísmo por deseary lograr- ser madre a una edad tan avanzada: una libre y egoísta elección de ser madre tardía, frente al derecho del recién nacido a recibir la garantía de los cuidados maternos -que por su edad se ponían en entredicho-.

Como decíamos al principio...ojos que no ven, corazón que no siente. Pero no es la primera mujer en España que en los últimos años toma esta decisión -y las redes sociales toman nota-, apoyándose en la ciencia biotecnológica y en su deseo y libertad personal para ser madre. Comienza un debate social en las redes, donde todas las opiniones serán

\footnotetext{
${ }^{21} \mathrm{http}: / /$ www.cuatro.com/cronicacuatro/etico-mama-sesenta-Hoy-Cronica_2_2324730094.html

${ }^{22}$ Lina Álvarez.
} 
escuchadas, olvidando en gran número de ocasiones que la libertad de expresión tiene - $\mathrm{O}$ puede tener- limitaciones jurídicas ${ }^{23}$.

La situación de Lina Álvarez se ha tratado paralelamente al caso de Mauricia Ibáñez: una burgalesa que a los 64 años de edad, tuvo por cesárea dos hijos. Si en el caso de Lina se aderezaba su edad junto a su estado de viudedad y el antecedente de un hijo con minusvalía -que convive con ella-, a Mauricia se le unía la circunstancia de que el tratamiento de fecundación lo realizó en Estados Unidos tras la retirada en 2014 de la custodia de su primogénita por desamparo -Junta de Castilla y León- ${ }^{24}$.

A todas luces nos encontramos ante una cuestión social, ética, biotecnológica y sanitaria, además de plantear potenciales repercusiones jurídicas.

Un asunto tan personal como la libertad para decidir ser madre o no, se visualiza lejos del ámbito público o social. Sin embargo de todos es sabido que en asuntos de familia personalísimos y privados-, la figura del Ministerio Fiscal -por ejemplo- aparece en nuestro ordenamiento como figura pública de protección al menor. ¿Existe en los casos de custodia de menores, un interés público a pesar de nacer en el ámbito privado? Por supuesto. Luego de la misma manera que en las separaciones y/o divorcios hay un interés público por el menor, ¿podría haberlo en el caso de la muerte de mujeres que son madres a edad tardía, sin cónyuge? Habremos de responder afirmativamente a esta cuestión, no por la edad de la madre, sino por el interés del menor. Separemos cuestiones.

¿Tiene sentido hablar de ética en este tipo de situaciones? La libertad de expresión es un derecho reconocido en el art. 20.1.a) CE. Luego podremos dar nuestra opinión a cualquier efecto en esta circunstancia, máxime cuando es un asunto donde la esfera moral de la persona -en un sentido u otro- se ve afectada. Las normas que rigen las conductas de las

\footnotetext{
${ }^{23}$ La libertad de expresión -art. 20.1.a) CE- se encuentra limitada por el derecho al honor -art. 20.4 CE-. Véase también la STS 417/2016, Sala 1 $1^{\text {a }}$, de lo Civil, Sección 1, 20 de junio de 2016.

${ }^{24}$ El motivo por el que Mauricia perdió la custodia de su primera hija, fue su incapacitación laboral por trastorno psicológico.
} 
personas en cualquiera de sus ámbitos, es parte fundamental de sus valores personales. Estos valores personales pueden ser comunes a una comunidad de personas: una sociedad concreta. Pero en la vida social no coincidimos todos en una única línea de pensamiento. La afectación moral o ética será diferente en cada ciudadano y por ende la conducta de las mujeres que deciden en libertad ser madres a edades avanzadas, podrá ser valorada positiva o negativamente dependiendo del receptor de la noticia.

En la situación anteriormente comentada de la señora Lisa Álvarez, precisamente el debate social la llevó a acudir al plató de una cadena privada -muy popular-, creyendo que su experiencia podría ayudar a otras mujeres en situaciones similares. Lo que encontró fue un grupo de personas cuya ética discrepaba respecto a su decisión de ser madre a los 62 años.

El debate se torna dificultoso no solo motivado por su edad, sino por sus circunstancias personales. Nos gustaría pensar que la pretensión no fue la de ser juzgada públicamente y que en todo caso el valor de su presencia era el de argumentar su decisión -libre y lícitade tener hijos a esta edad. El conflicto ético se endurece en cuanto se conoce el entorno de Lina. Ella es una mujer muy trabajadora, culta y educada - de hecho ha trabajado como médica toda su vida-. Pero su situación es realmente especial ya que enviudó hace unos años, quedando ella sola al cargo del único hijo fruto de su matrimonio: un adolescente con una fuerte minusvalía física y psíquica. Lina explicaba que el motivo que reforzó su paso para tener dos hijos más -ayudada por la tecnología biomédica-, fue precisamente su hijo enfermo. La soledad y la tristeza en la que podría verse sumergido su hijo adolescente cuando ella faltase, no hacía más que replantearse la posibilidad dejarle unos hermanos con los que ser feliz el resto de su vida. Es decir, ampliar la familia. Las explicaciones iniciales se tornaron justificaciones desde el momento que eran exigidas por sus entrevistadores -reconocidos jueces sociales ${ }^{25}$ a todas luces-.

\footnotetext{
${ }^{25}$ Personas públicas de alto reconocimiento social, las cuales influyen con su diálogo y pensamiento a una gran cantidad de personas, con el consecuente enjuiciamiento social que en gran número de ocasiones se desarrolla en paralelo a los procesos judiciales. Esta es una realidad que ha de tenerse en cuenta, por el
} 
Las posturas se duplicaron rápida y desequilibradamente. Por un lado ella defendía la alegría, la paz y la felicidad que los gemelos habían generado en su pequeña familia ahora numerosa-, comprobando así que su hijo mayor es más feliz desde que nacieron los pequeños, colmando de paz y felicidad a la madre. Los esfuerzos personales para esta mujer quedaron superados con creces en vista del resultado. Pudo tener a sus dos últimos hijos, y los ha tenido felizmente sin exigir ayuda de nadie.

La postura opuesta plantea -sin embargo- encuentra únicamente problemas dignos de análisis:

1) Por la edad de la madre es muy probable que esta fallezca siendo aún menores de edad los hijos, con los consecuentes problemas sociales que esto podría acarrear. ¿Cuál es el coste económico que supondría para nuestra sociedad este tipo de situaciones?

2) El padre de su primer hijo falleció siendo desde entonces familia monoparental. La inseminación artificial con donación de óvulo, exime de responsabilidades de filiación ${ }^{26}$, por lo que en caso de que la madre fallezca...¿quién se haría cargo de los hijos pequeños y del mayor con minusvalía?

3) La madre cuestionada asegura no haber pedido ayuda económica a ningún organismo público: todos los gastos de la reproducción asistida los ha sufragado ella. Pero llegado el caso de su desaparición sería la Administración Pública la que habría de responsabilizarse de estos niños. ¿Qué ocurriría si todas las mujeres quisieran ser madres a esas edades y cómo podríamos sostener esta nueva situación económicamente partiendo de un sistema sanitario en crisis?

4) ¿Debemos marcar un límite legal -jurídico- respecto la toma de decisiones de este tipo?

calado tan extenso y profundo que puede llegar a provocar en nuestras sociedades ávidas de recepción informativa.

${ }^{26}$ Artículo 6 de la Ley 14/2006, de 26 de mayo, sobre técnicas de reproducción humana asistida. 
5) ¿Habría de regularse en todo caso, en qué situaciones sería viable o no este tipo de decisiones? ¿Se podría concretar un númerus clausus de circunstancias en las que se limitasen los casos para poder optar a ser madre a edades tardías? Por ejemplo la abuela tiene un hijo biológico para su hija, la cual no puede gestarlo. ¿Sería esto ético? ¿No tendrían conflictos morales? ¿Las relaciones familiares...no se verían desgastadas si no rotas en algunos casos?

6) ¿Hasta qué punto podemos manejar la ciencia en beneficio del capricho, del deseo o de la libertad humana?

7) Y los hijos nacidos en esta situación....jtienen derecho a quedarse sin madre tan pequeños? Existe una alta probabilidad de que esto ocurra. ¿Qué derechos les asistirían si al morir la madre quedasen solos y sin familia? ¿Es la mejor situación para un niño, o la situación ideal?

8) ¿Dónde está el límite entre la libre elección y la obligación responsable de un buen padre de familia?

9) ¿Debemos -en definitiva- regular al respecto?

Estas y otras cuestiones de menor calado fueron planteadas por periodistas -todas ellas mujeres- que representaban algunas de las diferentes situaciones sociales y laborales: asociación de mujeres feministas, mujeres a favor de la no maternidad, madres jóvenes, mujeres trabajadoras, etc. Un abanico de perfiles digno de un tribunal ético y moral, con agudas cuestiones preparadas y premeditadas, a las que la invitada no imaginaba siquiera podría llegar a enfrentarse.

Con independencia de la situación particular del citado debate, las cuestiones éticas o morales que se nos plantean habrán de valorarse desde un ámbito jurídico si no queremos 
perdernos en una discusión infructuosa. La proporcionalidad -principio general del derecho- habrá de tenerse en cuenta en cada situación personal para fundamentar las conclusiones. Por lo que procedamos a basar nuestras opiniones al respecto.

1) Por la edad de la madre, es muy probable que esta fallezca siendo aún menores de edad los hijos, con los consecuentes problemas que esto acarrearía.

Desde el punto de vista biológico y médico el aumento de edad conlleva mayor probabilidad de mortandad: principio basado en ciencias matemáticas. Pero esta situación ha de llevarnos a supuestos de hecho que por analogía son idénticos -la madre muere y el hijo se queda sin progenitores-, y sin embargo no se plantea duda o conflicto alguno frente a las mismas. Es el caso de las mujeres -que sin cónyuge o viudas-, al parir fallecen. No es necesario morir en el parto, ya que basta con que el hijo sea menor de edad y desaparezca la madre. El fallecimiento de esta también ocurre con frecuencia en accidentes - como los de tráfico- y sin embargo no se plantea dicha cuestión. Puede ponerse como ejemplo la desfachatez con la que muchos asesinos a través de la violencia de género matan a las madres de sus hijos - o exparejas con hijos ajenos-, y después se quitan la vida. Los menores se quedan sin sus progenitoras con edades muy cortas y sin embargo el dolor familiar y social producido por estos incompresibles actos, no nos replantea si debería limitarse a ciertas parejas tener -o no- hijos, ¿cierto?

La demagogia sobre este asunto no hace más que minusvalorar desde su origen el problema que puede llegar a plantearse, por lo que reconoceremos que las madres tardías tienen más posibilidades de morir cuando su hijo es aún menor de edad -respecto a otro grupo de madres más jóvenes-, pero no por ello ha de impedírseles serlo. Ello no debe ser impedimento -en ningún caso- para procurar limitar el derecho a decidir cuándo quieren ser madres. ¿Cuántos casos por enfermedad se dan en madres muy jóvenes que terminan falleciendo con las consecuencias comentadas, y nadie se atreve a elevar la voz? ¿O cuántos problemas se derivan de la orfandad materna de los hijos cuando son sus padres los asesinos de su madre? Es evidente que la Administración de Justicia en estos últimos 
casos habrá de contemplar tanto el riesgo como el amparo de estos menores de edad. Sin embargo los de madres tardías no nacen de un acto ilícito. Será en todo caso la Administración Social la que deba encargarse de estos menesteres.

2) El padre de su primer hijo falleció, y es familia monoparental desde entonces. La inseminación artificial con donación de óvulo, exime de responsabilidades de filiación, por lo que en caso de que la madre fallezca ... ¿quién se haría cargo de los hijos pequeños y del mayor con minusvalía?

Vista la Sentencia 41/2014 ${ }^{27}$ del Juzgado de lo Social n 3 de Almería, se deriva de la misma que el hecho de que el progenitor -varón- viva tras el fallecimiento de la madre, no evita que el menor quede en estado de desamparo. Con independencia de que el progenitor asesino de la madre viva, el menor ha de considerarse huérfano, perdiendo la custodia del hijo y por supuesto la patria potestad.

Cabría preguntarnos en este caso qué ocurre cuando una mujer embarazada enviuda durante la gestación, y antes de que el hijo sea mayor de edad, esta fallece. Estaríamos de facto ante una situación análoga a la de las madres tardías que sin cónyuge deciden tener hijos de manera unilateral -por ejemplo a través de la reproducción asistida-.

En el caso de la citada sentencia almeriense, la tía es la tutora de la menor, por lo que se ocupa de cuidar y velar por los intereses de su sobrina. En la mayoría de los casos resultantes de violencia de género, es muy frecuente que sean las abuelas las que retoman el cuidado y protección sobre estos. En los últimos cuatro años han muerto 168 mujeres asesinadas por violencia de género en España, y la mayoría de ellas tenían hijos a cargo.

\footnotetext{
${ }^{27}$ La Sentencia Social no 41/2014 del Juzgado de lo Social de Almería -recurso 299/2012 de 24 de enero de 2014-, es novedosa dado que los menores que perdían a sus madres por violencia de género -a manos de sus padres que continuaban vivos-, hasta este momento no eran considerados desamparados como huérfanos totalmente. Por ello las pensiones de orfandad no eran reconocidas en su totalidad. Sin embargo esta sentencia -promovido el recurso por la tía de la menor en cuestión-, entiende que a pesar de que el padre continúe vivo, a efectos de pensiones de orfandad, es como si estuviera muerto. Se le reconoce así una pensión completa a pesar de que el padre viva, por el hecho de que la madre muriese a manos de su padre.
} 
Las familias procuran recomponerse frecuentemente con escasas o nulas ayudas económicas para tales fines, ya que muchos de ellos no cobran pensiones de orfandad por continuar vivo su progenitor. Esta cuestión es digna de un profundo análisis y debate, pero en el que estamos insertos - por analogía-, nos encontramos con madres tardías que lógicamente a su vez, no pueden contar con sus madres -abuelas de los menores- para poder continuar con la labor de cuidado y protección del hijo huérfano.

En el caso de Linda, ella misma valoró la posibilidad de morir antes de que sus gemelos fuesen mayores de edad y organizó - como cada vez es más frecuente realizar en últimas voluntades- la sucesión: la tutela bajo la que sus hijos quedarían en custodia. Ningún Ministerio Fiscal de Menores tendría que esforzarse en buscar soluciones, ya que confió en su hermana -más joven que ella- para tal fin. Dicho de otro modo, previó esta circunstancia dejando asegurada la continuidad del cuidado de sus hijos. En ningún caso solicita ni pide ayuda a las Administraciones Públicas para este fin, aunque en nuestra opinión los hijos son dignos merecedores del mismo amparo jurídico y económico.

Atacar literalmente a una persona como Linda en base a supuestos de hecho posibles más o menos remotos- con la intención de reprochar su irresponsabilidad frente a su decisión unilateral de tener dos hijos con 62 años, equivaldría en derecho -por equidada reprochar a una madre que sufre violencia de género a abandonar las posibilidades de ser madre con otra pareja, por las probabilidades de que su expareja pudiera matarla a ella o a sus hijos. Sería kafkiano prohibir en la circunstancia citada la libertad de elección que una mujer toma mediante su decisión de ser madre, ya sea por primera vez o tras haberlo sido. ¿Qué tipo de libertad absoluta ampara a la sociedad en general para prohibir a una madre tardía a tener hijos? Libertad y despotismo...¿cuál es la línea divisoria?

3) La madre cuestionada indica que no ha pedido ayudas económicas a ningún organismo público -todos los gastos de la reproducción asistida los ha sufragado ella-. Pero llegado el caso de su desaparición, será la Administración Pública la que habría de responsabilizarse de estos niños. ¿Qué ocurriría si todas las mujeres quisieran ser 
madres a esas edades y cómo podríamos sostener esa situación económicamente a partir de nuestro sistema sanitario en crisis?

Sin entrar a valorar si el sistema sanitario español debería o no costear los gastos de la reproducción asistida en estos casos -asunto delicado-, queda meridianamente claro que la toma de decisiones de la mujer al respecto tiene su base en una profunda seguridad personal, recordando a su vez que hoy día son casos excepcionales. Un embarazo es un proceso con enormes cambios en la mujer: tanto físicos como psicológicos. Suelen ser nueve meses donde el cuerpo experimenta aumento de peso y de tensión arterial, dolores abdominales, etc. No suele ser un plato de buen gusto como norma general, más la ilusión del nacimiento de un hijo supera con creces las molestias y agravios a los que pueda enfrentarse -en ese periodo y en los venideros-.

Las madres que con edad avanzada deciden serlo, hemos de entender que han tomado sus decisiones basadas en una especial planificación, cuestión que otros grupos de madres demasiado jóvenes -por ejemplo con 15 años-, no tienen en cuenta. ¿Por qué no está bien visto que una señora de 64 años con una excelente salud, autónoma y con independencia económica, decida tener un hijo y no sentimos lo mismo cuando una adolescente -sin formación, sin el desarrollo físico ni psíquico total de su cuerpo, sin autonomía personal siquiera como menor de edad que aún es-, sea madre a estas tempranas edades?

La respuesta a esta cuestión ha de basarse en el principio de igualdad, ya que no hay noma alguna en la que el Estado español prohíba ser madre a los 16 años. De igual manera la edad no puede ser óbice para impedir la libre toma de decisiones para ser madre a ninguna mujer, a ninguna edad. La naturaleza de cada mujer le indica el límite de su propio cuerpo desde el aspecto fisiológico hasta el anímico y psíquico. Lo cierto es que son mucho más abundantes los casos de maternidad temprana que las tardías.

Otra cuestión a debatir en esta comparativa sería la capacidad de obrar en ambas circunstancias. Es decir, la mayoría o minoría de edad de la madre. El art. 199 del Código 
Civil español -Título IX De la incapacitación-, indica expresamente que nadie puede ser declarado incapaz sino por sentencia judicial en virtud de las causas establecidas por la ley. En la misma línea indica el art. 200 CC: Son causas de incapacitación las enfermedades o deficiencias persistentes de carácter fisico o psíquico que impidan a la persona gobernarse por si misma.

Al hilo es estos dos artículos jurídicos, tildar de incapaz a una señora por tener un bebé a los 64 años de edad, cuanto menos podría ser objeto de demanda si no de querella judicial. No existe ningún tipo de test o cuestionario -faltaría más-, el cual sea necesario superar obteniendo así la capacidad de la mujer para ser madre. Si no existe enfermedad o deficiencia persistente -física o psíquica- que le impida gobernarse por sí misma, ¿por qué dudamos de sus capacidades personales como madre por tener una edad avanzada? ¿Acaso no hay menores de edad que a todas luces no están capacitadas para serlo y sin embargo lo son sin ser tachadas de irresponsables? Precisamente la -total-capacidad de $o_{b r a r}{ }^{28}$ en nuestro ordenamiento jurídico se adquiere con la mayoría de edad-dieciocho años-. Luego jurídicamente los actos de los menores de edad pueden derivar en responsabilidad de los padres. A nadie se le ocurriría sancionar a unos padres cuya hija se ha quedado embarazada a los 17 años, ¿cierto? ¿En base a qué circunstancia antijurídica habríamos de limitar -y por tanto prohibir- la decisión de ser madre a cierta edad?

4) ¿Debemos marcar un límite legal-jurídico- en la toma de decisiones de este tipo?

Acabamos de preguntarnos esta cuestión desde otro prisma. Regular una edad límite para ser madre equivaldría a plantearnos cuestiones homólogas como la de plantear jurídicamente un límite de edad para que los hombres no puedan ser padres a partir de la que se considerase. En consonancia con lo que se debate basta con acudir a nuestra carta

\footnotetext{
${ }^{28}$ Según el art. 315 CC: La mayor edad comienza a los dieciocho años cumplidos. Para el cómputo de los años de la mayoría de edad se incluirá completo el día del nacimiento.

Según el art. 322 CC: El mayor de edad es capaz para todos los actos de la vida civil, salvo las excepciones establecidas en casos especiales por este Código.
} 
magna para recordar que es digno de protección según el art.10 CE: 1. La dignidad de la persona, los derechos inviolables que le son inherentes, el libre desarrollo de la personalidad, el respeto a la ley y a los derechos de los demás son fundamento del orden político y de la paz social. 2. Las normas relativas a los derechos fundamentales y a las libertades que la Constitución reconoce se interpretarán de conformidad con la Declaración Universal de Derechos Humanos y los tratados y acuerdos internacionales sobre las mismas materias ratificados por España. Tener que explicar y sobre todo fundamentar estos preceptos constitucionales, es a todas luces innecesario.

No obstante en la búsqueda de limitaciones en función de la edad para ser madre, no hemos podido encontrar ninguna normativa española que le dedique un solo reglón a este asunto. Igualmente la ONU, la OMS y los Tratados Internacionales a los que España se ha ido adhiriendo con el paso del tiempo, tampoco contemplan esta delimitación de ninguna manera. Ciertamente las técnicas reproductivas -no existentes hasta hace pocos años-, no posibilitaban que mujeres de edad avanzada pudieran plantearse siquiera ser madres. Pero la aplicación de la tecnología biomédica en estos casos no puede servir de excusa para su prohibición jurídica, de la misma manera que teniendo herramientas en el ordenamiento y en biomedicina para tomar la decisión de interrumpir la gestación, no se utiliza de manera imperativa. Dicho de otro modo, el hecho de que la Ley del aborto sea un reconocimiento de la actualidad jurídica en España, y habiendo tecnología para aplicarla sin riesgos para la madre, no significa que se limite la edad de la madre obligatoriamente para abortar en casos de menores de edad. Si la tecnología se usa para posibilitar la interrupción del embarazo sin que este sea prohibitivo en ningún caso, ¿por qué habríamos de plantearnos una regulación restrictiva de aplicación según la edad tardía- de la madre? La aberración de obligar a abortar a una mujer exclusivamente por su edad -solo en función de su edad-, sería eso: una barbarie jurídica. Distinto es el riesgo que puede una mujer tener al parir con 10 años o con 85 . Pero dejemos esos extremos que sin duda son extremadamente extraños en nuestra sociedad, y que lógicamente merecen un estudio y análisis mucho más personalizado del que en este artículo tratamos. 
Es cierto que los casos de mujeres entre 60 y 80 años son realmente escasos en el mundo. Pero hemos de reconocer que la mujer ha ido posponiendo su deseo de ser madre -por diferentes motivos ${ }^{29}$-, llegando edades más elevadas que en otros momentos de nuestra sociedad. La edad media en la que la mujer tiene su primer hijo ${ }^{30}$, ha aumentado en España a pesar de que el factor migratorio tiende bajar esta edad.

5) ¿Habría de regularse en todo caso? En qué situaciones sería viable o no este tipo de decisiones? ¿Se podría concretar un númerus clausus de circunstancias en las que únicamente sí se podría optar a ser madre a edades tardías? (Por ejemplo la abuela tiene un hijo biológico para su hija que no puede tenerlos? ¿Sería esto ético? ¿No tendrían conflictos morales? ¿Las relaciones familiares...no se verían desgastadas si no rotas en algunos casos?

La regulación o no de una situación jurídica dependerá de la necesidad de la misma, cuyos casos a veces vienen acompañados de un clamor social -como ocurrió con la regulación del aborto en España-, y en otros casos de un menor impacto social en cuanto a la cantidad de afectados, pero no por ello minusvalorado el conflicto que plantean. Son ejemplos de estas últimas situaciones la eutanasia o la maternidad subrogada. Se valora a través del debate social la necesidad de regular - o no- estas situaciones en las que las personas ven o sienten limitados sus derechos a la toma de decisiones, habiendo soluciones tecnológicas que permitirían -llegado el caso- aplicarse a cada caso.

\footnotetext{
${ }^{29}$ Los principales motivos por los que la mujer española pospone la edad para ser madre primeriza actualmente hasta una edad media de 32 años-, suelen ser por su incorporación al mundo laboral -lo cual puede conllevar retrasar mucho más esta edad-, la falta de compromiso respecto a su pareja para este fin compartir un hijo en común-, necesidad de independencia y estabilidad económica con la que afrontar los gastos que un hijo genera, la infertilidad - provocada en muchas ocasiones por la edad tardía a la que se procura tener el primer hijo- y su bienestar personal -el cual puede ver reducida su calidad de vida económica en el caso del nacimiento de un hijo-.

${ }^{30}$ En el año 2015 ronda los 34 años de edad media en madres primerizas españolas.
} 
Así observamos que en el supuesto de la eutanasia ${ }^{31}$ se están realizando propuestas legislativas para su amparo a través del ordenamiento jurídico, al igual que la maternidad subrogada $^{32}$ va encaminada hacia una posibilidad que podría materializarse legislativamente conforme al debate social y jurídico existente en la actualidad.

Sin dejar en el olvido los motivos por los que podría necesitarse una regulación respecto a la maternidad tardía, parece obvio que son situaciones realmente escasas las que se producen en la actualidad, y lógicamente se daría escasamente en un futuro -aunque ello no signifique que por la menor aplicación no haya necesidad regulatoria-. La muerte digna nos atañe a toda la sociedad, y desconocemos qué personas habrán de sufrir situaciones extremas en las que su cuerpo ya no soporte más dolor, o situaciones de desamparo personal y/o físico, bien por falta de medios paliativos efectivos o por la rotura espiritual de la persona ante un inacabable rosario de calamidades por la que tanto el enfermo como su entorno familiar y afectivo, se ven obligados a pasar.

En nuestra opinión la maternidad tardía no da motivos para su expresa regulación, siempre que se cubran con garantías suficientes las necesidades sociales que pudieran surgir de la misma. Dicho de otro modo, la sociedad podría no querer cubrir el coste de pensiones de orfandad, ayudas a la maternidad, etc., derivadas de estos nacimientos de seres humanos donde las madres tienen una edad avanzada en la propia gestación, si los casos fueran continuos y multitudinarios. ¿Pero estamos ante estas circunstancias?

\footnotetext{
${ }^{31}$ Es el caso de la Proposición de Ley Orgánica sobre la Eutanasia, publicada en el Boletín Oficial de las Cortes Generales -Congreso de los Diputados- con fecha 30 de enero de 2017, presentada por el Grupo Parlamentario Confederal de Unidos-Podemos-En Comú Podem-En Marea. El 21 de marzo de 2017 no se aprobó la tramitación de la proposición de ley por votar en contra el PP y por la abstinencia de PSOE y Ciudadanos. No obstante una semana más tarde -el 28 de marzo de 2017-, el grupo parlamentario Ciudadanos logró con su Ley de muerte digna, el consenso que Podemos no obtuvo con la eutanasia, con el apoyo tanto de PP como de PSOE.

${ }^{32}$ El 27 de junio de 2017 el Grupo Parlamentario Ciudadanos, registró en el Congreso una proposición de ley para regular la gestación subrogada, cuyo objetivo necesariamente habría de tener carácter altruista. Igualmente se limitaría a la mujer a una serie de condiciones como tener cumplidos al menos 25 años, haber sido madre con anterioridad, tener una situación económica estable y no permitir más de dos gestaciones subrogadas a lo largo de su vida. Un detalle es que se limitaría la edad en un mínimo pero no en un máximo, cuestión que nos ocupa en este artículo.
} 
Precisamente uno de los argumentos jurídicos más sólidos para sustentar la opción de no necesidad de regulación, se basa en las situaciones de facto que se producen y resuelven en la actualidad a través de los servicios sociales públicos españoles ${ }^{33}$, a través de principios generales del Derecho como la analogía y la proporcionalidad.

A nadie se le ocurriría pensar que si una madre durante el parto muriese, el hijo o los hijos nacidos, se verían desprotegidos en función de si la madre era menor de edad, mayor de edad, o fuese de muy avanzada edad. Ni ética, ni moral, ni jurídicamente admitiríamos los españoles un desamparo derivado únicamente por la edad de la gestante. De la misma manera ante una mujer con problemas de fertilidad cuyo tratamiento posibilitaría su deseo de ser madre - hoy día regulada y permitida este tipo de aplicación de tecnologías embrionarias-, no nos atrevemos a cuestionarla si tiene 28 años, 43 ó 55 años. ¿Por qué sí 63 o 75? Dejamos a un lado esta cuestión pues las madres tardías -hoy en España-, se están costeando de manera privada las posibilidades de serlo, sin pedir ayuda al sistema sanitario público.

Hemos de ser cautos no confundiendo el concepto salud con edad. Una mujer con 65 años es posible que a pesar de que necesite ayuda biotecnológica para concebir, tenga un organismo físicamente más adecuado que una de 25 . Esto es una realidad que llegado el caso hipotético y posible de regulación, obligaría a "no prohibir", sino a delimitar -en todo caso- las condiciones físicas y psicológicas de la potencial madre, no en función de su edad, sino de sus capacidades ${ }^{34}$.

La Ley 14/2006, de 26 de mayo, sobre técnicas de reproducción humana asistida, indica expresamente en su artículo 3 -Condiciones personales de la aplicación de las técnicas-

\footnotetext{
${ }^{33}$ Asistencia médica de la Seguridad Social, pensiones, escolarización, reconocimiento de filiación, etc.

${ }^{34}$ El artículo 3 -Condiciones personales de la aplicación de las técnicas- de la Ley 14/2006, de 26 de mayo, sobre técnicas de reproducción humana asistida, indica expresamente: Las técnicas de reproducción asistida se realizarán solamente cuando haya posibilidades razonables de éxito, no supongan riesgo grave para la salud, física o psíquica, de la mujer o la posible descendencia y previa aceptación libre y consciente de su aplicación por parte de la mujer, que deberá haber sido anterior y debidamente informada de sus posibilidades de éxito, así como de sus riesgos y de las condiciones de dicha aplicación.
} 
lo siguiente: Las técnicas de reproducción asistida se realizarán solamente cuando haya posibilidades razonables de éxito, no supongan riesgo grave para la salud, física o psíquica, de la mujer o la posible descendencia y previa aceptación libre y consciente de su aplicación por parte de la mujer, que deberá haber sido anterior y debidamente informada de sus posibilidades de éxito, así como de sus riesgos y de las condiciones de dicha aplicación. La reproducción asistida está amparada por la ley en España, y prevé su aplicación solo "cuando existan posibilidades razonables de éxito" sin poner en riesgo grave a la salud de la mujer: condición indispensable para hacer que ésta sea posible.

Por un lado, observamos que el límite impuesto por la ley no se sustenta en la edad de la madre, sino en el riesgo que esta pudiera tener en este proceso de fecundación. En la mayoría de los casos -si no en todos-, una mujer española de 60 años de edad no podrá ser madre de forma natural. De hecho se estima que la edad media de la mujer española al entrar en el periodo de menopausia, es de 51.4 años, oscilando entre los 48 a 54 años. La mayoría de las madres tardías habremos de evaluarlas como tal, cuando necesitan precisamente de ayuda biotecnológica, ya que si de manera natural puede embarazarse, significa que su cuerpo está preparado naturalmente para gestar, por lo que no debería hablarse en estos casos de maternidad tardía tal cual. Otra casuística digna de valoración y estudio en la que no podemos profundizar en este momento.

Si la ley permite la aplicación de técnicas de reproducción solo en los casos en los que la mujer está fuera de peligro y con posibilidades de éxito, es evidente que las mujeres que deciden ser madre a los 65 años, han pasado pruebas y filtros médicos que la considerarán apta para estos fines.

Por otro lado no todas las mujeres que superan los 50 años quieren tener hijos a esas edades, reduciéndose exponencialmente su interés cada año que transcurre. Así observaremos los motivos por los que estas madres tardías toman sus decisiones, antes de intentar vetar con herramientas jurídicas sus posibilidades basándonos en cánones éticos o morales, individuales y no generales. 
En la actualidad existe una fuerte confrontación respecto al término jurídico tener derecho $a$, ya que muchos juristas no catalogan ciertas situaciones personales e individuales como derechos: no los reconocen como tales. Por ello una parte importante de la doctrina no reconoce la maternidad, la paternidad o el aborto -entre otras-, como un derecho tal cual. No es la finalidad de este artículo despiezar el concepto y debatirlo. No obstante en nuestro ordenamiento no se encuentra duda alguna cuando a pesar de no reconocerlos como derechos absolutos, se estiman como evidentes situaciones no prohibidas, dignas de amparo jurídico y cuyas características tácitas se traducen en posibilidades lícitas. Posibilidades que generan situaciones fácticas y reales, las cuales una vez desplegadas, $s i$ generan derechos y obligaciones.

Por suerte el ordenamiento jurídico español es sumamente positivo en su creación normativa, en el sentido de que regula supuestos de hecho sin procurar su prohibición ${ }^{35}$. De hecho con frecuencia la taxativa prohibición de normas provoca generalmente un previo rechazo social y automático a la proposición de la misma. Así por ejemplo ante la amenaza proclamada por los detractores de la maternidad subrogada, cuando consideran que ésta sí está regulada a través del contenido prohibitivo del artículo 10.1 de la Ley 14/2006, de 26 de mayo, sobre técnicas de reproducción humana asistida, no podemos quedarnos impasibles ante la mera interpretación literal de dicho artículo. Estaría fuera de todo orden interpretativo y carente de sentido común, cuando en la situación simétrica se protege y regula jurídicamente la capacidad para contratar a través de la donación, óvulos y esperma ajenos para aplicar precisamente la misma técnica reproductiva en la fecundación in vitro.

\footnotetext{
${ }^{35}$ Un claro ejemplo se observa en la esfera del ámbito penal. La tipificación en el CP es positiva en el sentido de que cuando tipifica p.e. el delito de asesinato, no indica imperativamente "no matarás" -a todas luces originario de fundamentos básicos religiosos-. Precisamente en el Título I Del homicidio y sus formas, el artículo 138 indica expresamente: 1. El que matare a otro será castigado, como reo de homicidio, con la pena de prisión de diez a quince años....
} 
El art. 10.1 -gestación por sustitución- de la Ley 14/2006, de 26 de mayo, indica expresamente: 1. Será nulo de pleno derecho el contrato por el que se convenga la gestación, con o sin precio, a cargo de una mujer que renuncia a la filiación materna a favor del contratante o de un tercero. ¿Por qué no puede una madre gestante donar su capacidad para recepcionar y hacer posible el nacimiento por subrogación, y otra madre sí puede donar sus óvulos para que otra los utilice en su gestación?

Un claro ejemplo es el supuesto de hecho de una mujer de 50 años cuya hija de 25 tiene óvulos en perfecto estado, pero su útero no le permite gestar. Su marido tiene semen saludable y por vía de la fecundación invitro, la abuela del gestado es implantada para poder dar a luz a su propio nieto. ¿Por qué ha de haber en este caso un contrato? Genéticamente es hijo de su hija y su yerno: es decir, su nieta. Busquemos soluciones jurídicas a estos supuestos de hecho a todas luces lícitos, sin pretender sesgar posibilidades por el hecho de un artículo que prohíbe la forma jurídica del contrato, como excusa para limitar estas situaciones de manera general y global.

Es evidente que los asuntos en Biomedicina y Biotecnología no pueden resolverse con afán lucrativo en España: no compramos riñones o corazones. Se donan. ¿Sin embargo no puede donarse el espacio uterino para tales fines -a todas luces humano y ético-, si la Biotecnología lo permite? ¿Nos encontramos ante un conflicto social o ante un conflicto personal de unos pocos? Por supuesto podrán darse supuestos en los que por salud hacia la madre o bien por otras incompatibilidades -los cuales llegados a un momento de creación normativa podrían clarificarse-, la madre tardía no deba -ni pueda- tener hijos en ese momento de su vida. Si tiene una enfermedad importante y degenerativa en los huesos -por ejemplo artritis reumatoide-, se le vetará sus posibilidades por la enfermedad, no por la edad. En este caso se fundarían los motivos en una norma previa y existente ${ }^{36}$. En definitiva: ¿hemos de realizar hoy una regulación con númerus clausus en cualquier situación análoga? En nuestra opinión, no.

\footnotetext{
${ }^{36}$ Ley 14/2006, de 26 de mayo, sobre técnicas de reproducción humana asistida.
} 
6) ¿Hasta qué límite podremos manejar la ciencia en beneficio del capricho, del deseo o de la libertad humana?

Es obligado contestar sin reparos -dadas las circunstancias-, que por suerte hoy día la mayoría de los embarazos son deseados, y en muchas ocasiones programados y planificados a capricho de la gestante. ¿Hay algo más íntimo y personal que querer ser madre? ¿Acaso no es un deseo antes que una necesidad imperiosa que tiene la mujer? ¿Por qué con 30 años no consideramos un capricho embarazarse y a los 55 sí? Jurídicamente no tiene ningún peso basarse en castigar como capricho, ingenuidad o egoísmo, algo tan meditado como lo es la planificación de un embarazo en estas circunstancias. Tengamos en cuenta que suelen ser madres solteras o viudas, mayores, con poder adquisitivo alto - para abonar los gastos derivados de todo el proceso-, con experiencias previas de maternidad en casi todos los casos, etc. No seremos nosotros quienes generalicemos la afirmación de que estas, no están preparadas para ser madres.

7) Y los hijos nacidos en esta situación .... ¿tienen "derecho” a quedarse sin madre tan pequeños, con bastante probabilidad? ¿Qué derechos les asistirían si al morir la madre solo quedan ellos? ¿Es la mejor situación para un niño?

Si convenimos que la maternidad no es un derecho, habremos de afirmar que quedarse sin madre, tampoco lo es. Esto último ni siquiera es una opción como la maternidad: la muerte de la madre es una circunstancia sobrevenida. Luego la aseveración es en su totalidad de índole ético y sin base jurídica alguna.

Los detractores de la maternidad tardía suelen apelar al coste que administrativamente supone para el Estado o las Comunidades Autónomas, las potenciales ayudas requeridas para las posibles circunstancias en las que la madre muera, siendo el hijo aún menor de edad. Ante esta apelación no podremos más que sorprendernos. Una persona al nacerviva- es considerada a todos los efectos jurídicos persona, adquiriendo en el momento de 
su nacimiento los mismos derechos que cualquier otro. Caso de que la madre muriese siendo el hijo menor de edad -cuya probabilidad puede ser alta-, ¿dudamos a estas alturas de sus derechos? Por supuesto que estamos obligados jurídicamente -además de éticamente-, a proteger a estos niños desde cualquier ámbito. A proporcionarle educación, alimento y cobijo, y en definitiva a procurar su correcto desarrollo como persona en un entorno saludable.

¿Acaso hemos de sentenciar las potenciales situaciones de los infantes en pro de sus incontrolables futuros, para decidir hasta cuándo una mujer puede o no tener hijos? Si nos planteamos esta situación, ¿por qué de manera análoga no vetamos por ley a aquellas mujeres que padecen enfermedades coronarias, ya que pudieran tener problemas en el parto -llegando incluso a morir-, con el consecuente coste económico que la sociedad habría de respaldar por ellas? Estamos ante el caso de prestaciones por orfandad, becas escoleras, familia monoparental, etc. Meditemos un poco al respecto.

8) ¿Dónde se encuentra el límite entre la libre elección y la obligación responsable de un buen padre de familia?

La pregunta incontestable. ¿Quién sabe si antes de ser padre o madre, va a ser bueno o no en esta labor? ¿Qué seguridad tiene la sociedad de que todos los progenitores son buenos padres de familia cuando la violencia de género, el abuso de menores por parte del padre - o madre- y el abandono y falta de cuidado de hijos menores está a la orden del día en cualquiera de nuestros noticiarios? En realidad no hay una vara de medir que posibilite delimitar la responsabilidad. Lo que si puede hacer la justicia a través del Derecho, es actuar cuando esa responsabilidad no es ejercida correctamente.

El derecho nos enseña que las obligaciones pueden ser catalogadas por su origen, como obligaciones naturales u obligaciones jurídicas. Nadie puede exigir jurídicamente a un padre que sea cariñoso con su hijo, le abrace a diario o le dedique parte de su tiempo libre. Sin embargo sí es una exigencia u obligación natural, que un padre bese y acaricie a su 
hijo, que le dedique tiempo y sea cariñoso con él, que le lea cuentos cuando es pequeño.... ¿Jurídicamente estamos habilitados para limitar la libre elección de la posibilidad de tener un hijo? Creemos que no, y mucho menos amparándonos en la edad de la madre. Cuántas personas jóvenes no están preparadas ni física, ni psíquica, ni intelectualmente para ser madres y sin embargo no prohibimos o limitamos normativamente la edad para tal fin?

\section{9) ¿Debemos -en definitiva- regular al respecto?}

Esta cuestión se contesta con el compendio del resto de respuestas: no es necesario. Cuestión diferente sería que la madre tuviera una discapacidad, o una enfermedad incurable y quisiera a toda costa ser madre. Entonces la edad no sería el factor determinante, sino un supuesto de hecho diferente al que se plantea en este momento.

Desde luego no pondremos en duda que nos hallamos ante un asunto muy recurrente y sobre el cual -claro está- todos tenemos derecho a opinar. Derecho a opinar, sí. ¿Derecho a plantear esta situación como irresponsable, ilícita o incluso descabellada hasta el punto de afirmar que esa conducta solo puede derivar de un problema psicológico, neurológico o psiquiátrico? Entendemos que no solo es innecesario regular esta cuestión, sino que no tiene sentido. El derecho actual es tal cual, precisamente por la superación que a lo largo del tiempo han sufrido las sociedades que nos preceden. Los pasos jurídicos han de ser encaminados hacia el beneficio de la persona -no en su contra-, sin perder de vista los bienes jurídicos públicos dignos de protección.

¿Tiene la ciudadanía derecho a plantear posibles incapacidades por darse circunstancias poco usuales en ella? Mientras el ciudadano desconectado de las nuevas tecnologías desconocía estos casos globales, no ocurría absolutamente nada. La señora que con 60 años se embarazaba hace un siglo, se veía como una capacidad biológica que -in extremisacontecía con muy poca frecuencia, pero en ningún caso se valoraba como irresponsabilidad o capricho. Todo lo más esta situación se consideraba un capricho de la naturaleza, sin crítica admisible. 
En la actualidad -donde incluso el presidente de los EEUU se comunica a través de twitter-, ¿realmente tiene la sociedad derecho siquiera a plantear incapacidades o limitaciones a libertades hasta ahora respetadas y reconocidas, por el mero hecho de tener más o menos edad? La cuestión se torna más retorcida cuando -reconozcámoslo- la persona se siente arropada por otras en las redes sociales, confundiendo el derecho a la toma de decisiones personales con el derecho a opinar sobre dichas decisiones -de manera grupal-, creyendo que la coincidencia ideológica legitima sus causas.

Esto es lo que ha ocurrido en los últimos años en algunos países - como España-, donde las redes sociales han tenido tal aceptación que estas han servido de plataforma política para planteamientos ideológicos ${ }^{37}$. Así la tecnología permite plasmar en tiempo real la opinión de cada persona dispuesta a ello, siendo cada vez más recurrentes las apps cuya gratuidad ofertan la posibilidad de sentirnos jueces desde los sillones de nuestros salones $^{38}$. No debemos temer las posibilidades tecnológicas ofertadas ya que potencian el tráfico e intercambio de información, pero sin olvidar tener en cuenta que la sociedad no controla -aún- este medio digital por el que se opina, se critica e incluso se extralimitan actuaciones insertas en las esferas más personales del ser humano.

Como ejemplo de rabiosa actualidad podemos referir la app, ¿cómo lo ves? del programa de Radio Televisión Española -cadena televisiva $\mathrm{La} \mathrm{1-,}$ presentado por Carlos Herrera. En dicha app -destinada al uso exclusivo de smartphones- solicitan el nombre y a ser posible una fotografía que identifique al usuario, enviándole cuestiones de diversa índole para conocer la opinión de los usuarios que quieran libremente opinar al respecto. Una de

\footnotetext{
${ }^{37} \mathrm{Ni}$ que decir tiene que las principales plataformas sociales -en especial Twitter-, se han convertido en un verdadero y fidedigno barómetro de las citas electorales en España. La influencia que esta supone en la sociedad, es merecedora de toda la atención tanto en grupos políticos como en candidatos -especialmente en los momentos de campaña-.

${ }^{38}$ Es el caso de las apps que permiten dar la opinión de cualquier persona en tiempo real, y cuyo objetivo de la aplicación es la de conocer las opiniones del público, llegando incluso a crear series televisivas cuyos desenlaces dependan del deseo del mismo. Llegando así a alterar por completo la idiosincrasia propia de los guionistas, obligando a estos a adaptarse al gusto del consumidor, con la consecuente pérdida de naturalidad, frescura y originalidad de las mismas, en búsqueda de elevar los índices de audiencia: marketing económico.
} 
las últimas cuestiones planteadas es la siguiente: ¿recurriría a un vientre de alquiler? En porcentajes un $17 \%$ contesta si, sin $d u d a$, un $32 \%$ solo si es legal, y un $51 \%$ no por principios. Aunque no estemos hablando de unas estadísticas fiables como pueden ser las generadas por del Instituto Nacional de Estadística -INE-, lo cierto es que el receptor las considera inmediatamente fidedignas. La sociedad recibe una información que tiende a considerar veraz y general, con el consecuente equívoco -o no- sobre las cuestiones planteadas. La confusión está servida.

Para empezar podríamos alegar que solo opinan personas que tienen acceso a este tipo de medios electrónicos y por tanto la limitación de estas respecto a la totalidad o generalidad social, queda lógicamente mermada a un sector muy específico ${ }^{39}$. Llegaríamos sin duda a la conclusión de que estamos tan mediatizados, que cualquier tendencia ideológica que se transmite a través de las redes sociales - apps incluidas-, arrastran la opinión social sin tener en cuenta la veracidad o alcance de las mismas. Por ello a la cuestión de si las redes han de servir para tener en cuenta las opiniones de la sociedad en general, deberíamos recordar lo expuesto y contestar no, o al menos tenerlas en cuenta con la cautela necesaria ya que conocemos el limitado alcance que estas tienen, y la ausencia de opinión de quienes no trafican con sus opiniones, y legítimamente -en todo caso-, habrían de ser igualmente escuchadas. Sin embargo puede afirmarse que estas redes de intercambio de ideas y opiniones donde el tiempo de reflexión es ínfimo -si no inexistente-, arrastran masas por la propia condición del ser humano.

Trasladado todo este potencial mediático a la maternidad tardía habremos de concluir igualmente que en la sociedad actual no solo leemos la redacción de autores,

\footnotetext{
${ }^{39}$ Los teléfonos móviles inteligentes en España -smartphones- representan en 2016 el 87\% del total de teléfonos móviles, situándonos a la cabeza del resto de países europeos. La edad de inicio es muy temprana: en 2015 un $98 \%$ de los jóvenes de 10 a 14 años cuenta con un teléfono de última generación con conexión a internet: los niños de 2 a 3 años usan habitualmente los móviles de sus padres. El tráfico de datos móviles se multiplicará por 7 entre 2015 y 2020, por lo que se supone un incremento interanual de un 46\%. En 2016 y en todo el mundo, el uso de aplicaciones -apps- suponedla inversión del 54\% del tiempo invertido en el mundo digital. Los usuarios empiezan a acostumbrarse a pagar por el uso de estas apps -app store-: los españoles que han pagado por una app ha crecido hasta situarse en un $46 \%$. El perfil de usuario de apps en España oscila entre los 25 y 34 años -Madrid, Barcelona, Granada-, el cual dedica una media de 3 horas desde los smartphones.
} 
investigadores, filósofos, políticos o escritores, sino que contestamos inmediatamente con el consecuente feedback. Este feedback puede aceptarse desde un prisma positivo ampliando pensamientos, posibilidades, reacciones, etc. Pero existe un prisma negativo importante, y es la posibilidad constante de caer en la tentación de dar por válido y veraz todo lo que se cruza en la redes gracias al interés de sus usuarios. La gran velocidad a la que se transmiten estas comunicaciones y el cada vez menor tiempo de reacción que tenemos para ser los primeros en presionar la tecla que nos catapulte a la posición de influencers, youtubers, it girls, smart girls, etc., nos obliga a contestar sin apenas pensar. Las madres tardías no han sido un objetivo ajeno a las mismas y virtualmente han sido pasto de todo tipo de opiniones.

Es aquí donde la ética ${ }^{40}$ y la moral ${ }^{41}$ pueden precipitarse hacia un pensamiento global mediatizado en el que el Derecho queda al margen -pudiendo coincidir o no-, con el consecuente riesgo de que se esté formando una ética en la sociedad derivada de la falta de reflexión y a extrema velocidad, cuyo fin sea el equívoco y por tanto la injusticia en última instancia. Una moral social derivada de un uso inadecuado de la información que empodera la misma sin tener en cuenta criterios tan importantes como la meditación, sobre las cuestiones que son o pudieran ser conflictivas en la sociedad.

Mahatma Gandhi nos dejó la siguiente reflexión: "Somos dueños de nuestros silencios y esclavos de nuestras palabras". Este abogado, político y activista indio del siglo XIX$\mathrm{XX}$, desconocía en el momento de su emisión el enorme alcance que casi un siglo después tendrían sus palabras en un mundo tan globalizado gracias a las redes sociales, inexistentes en los momentos de su propia vida.

A lo largo de la historia comprobamos que los grandes pensamientos e ideales, la base de la moral y la ética social, han ido construyéndose a base de tiempo: mucho tiempo. Sin

\footnotetext{
${ }^{40}$ Entendiendo "ética" como la elección propia que surge de tras la reflexión e interiorización que una persona realiza respecto a cierto tipo de situaciones y valores humanos.

41 "Moral" debemos entenderla como el conjunto de normas que actúan en la conducta personal desde el exterior o desde su subconsciente, partiendo de la ética propia.
} 
embargo nos hallamos ante una sociedad que opina de manera automática -casi autómata, con la consecuente pérdida de esencia en sus respuestas. Hay pensamientos que no requieren respuesta. La poesía no se escribe para ser criticada, tasada o valorada. Se escribe para su disfrute. Más en la actualidad todo pensamiento se debate, se critica, se enjuicia,.... ¿Dónde quedó el tiempo para reflexionar?

El posible conflicto surgido ante la maternidad tardía no puede ser considerado ni basado en exclusiva, en la edad a la que las mujeres deciden ser madres. El problema actual real, es que cualquiera puede opinar -hombres y mujeres, madres o no, mayores o jóvenes, homosexuales o heterosexuales, religiosos o ateos-, sin tener en cuenta las consecuencias de nuestras opiniones, especialmente cuando sobrepasamos límites morales, éticos o concernientes a derechos fundamentales de las personas. Parece que olvidamos que el derecho a opinar es limitado y todo, no vale.

La expresión y difusión de libre de pensamientos está ampliamente protegida en el ordenamiento jurídico español a través del artículo 20 de la Constitución Española ${ }^{42}$, el cual a su vez limita los mismos en pro de los derechos especialmente reconocidos como el derecho al honor, a la intimidad, a la propia imagen y a la protección de la juventud y de la infancia. ¿Somos conscientes de que sobrepasamos el límite constitucionalmente impuesto de respeto a otros derechos, cuando invadimos nítidamente el ámbito del honor de la madre tardía, su derecho a la intimidad, propia imagen y -para mayor escarnio- la protección de la juventud y de la infancia? Dado que de todos es sabido que la información en las redes virtuales deja una huella casi imborrable, ¿cómo podemos afirmar que los niños nacidos en estas situaciones están protegidos, cuando socialmente hemos

\footnotetext{
42 Art. $20 \mathrm{CE}$ : 1. Se reconocen y protegen los derechos: a) A expresar y difundir libremente los pensamientos, ideas y opiniones mediante la palabra, el escrito o cualquier otro medio de reproducción....d) A comunicar o recibir libremente información veraz por cualquier medio de difusión. La ley regulará el derecho a la cláusula de conciencia y al secreto profesional en el ejercicio de estas libertades. 2. El ejercicio de estos derechos no puede restringirse mediante ningún tipo de censura previa....4. Estas libertades tienen su límite en el respeto reconocido a los derechos reconocidos en este Título, en los preceptos de las leyes que lo desarrollan y, especialmente, en el derecho al honor, a la intimidad, a la propia imagen y a la protección de la juventud y de la infancia....
} 
extralimitado nuestras opiniones al respecto? Podrán leer sus casos personalísimos expuestos en la red públicamente. ¿Lícito y justo? Volvamos a meditar.

En el caso de las madres tardías nos hemos encontrado varias posiciones muy reforzadas por parte de sus detractores, las cuales atentan contra el respeto hacia las mismas:

a) Se alega incapacidad de la madre para la crianza del hijo: física y psíquica.

b) La madre es considerada irresponsable y carente de sentido común.

c) El futuro del hijo nacido es utilizado como motivo de peso para procurar una actitud de rechazo al intento de ser madres tardías, con la pretensión -amenaza jurídica en algunos casos-, en la que algunos juristas nos atrevemos a exigir regulación jurídica al respecto para la evitación de este conflicto inadmisible.

a) En el primero de los casos habremos de admitir que la incapacitación de una persona es un estado civil de la misma ${ }^{43}$, el cual solo puede proceder jurídicamente de sentencia judicial. El mero hecho de que una mujer tenga sesenta años de edad, no implica su automática falta de capacidad para criar a un hijo. No haremos referencia solo a la gestación y al parto -que a todas luces se comprueba que es posible y no suele generar problemas por el alto nivel de seguimiento médico que se aplica en estas situaciones ${ }^{44}$. Pretender juzgar la capacidad -o incapacidad- de las madres tardías, nos obliga a analizar la Ley 13/1983, de 24 de octubre, de Reforma del Código Civil en materia de tutela. Esta ley modificó en profundidad la redacción inicial y originaria del $\mathrm{CC}$, siendo uno de los

\footnotetext{
${ }^{43}$ El artículo 322 del Código Civil establece lo siguiente: El mayor de edad es capaz de para todos los actos de la vida civil,, salvo las excepciones establecidas en casos especiales por este Código.

${ }^{44}$ La autora Josefina Goberna Tricas publicó en 2011 un capítulo en la obra compartida "Bioética: la toma de decisiones", llamado Toma de decisiones en atención sanitaria a la maternidad: la voz de las mujeres. En él indica expresamente lo siguiente: En estos últimos años, algunas voces han asociado la tecnificación de la asistencia al nacimiento con la deshumanización de la atención sanitaria y han reclamado un retorno a una asistencia más respetuosa con la fisiología y consecuentemente, menos tecnificada. Se ha considerado que de esta forma la tención recobraría el punto de humanización que había perdido. Evidentemente optar por una asistencia más o menos tecnificada, implica decidir, escoger entre diferentes modelos asistenciales, y ello comporta aspectos éticos. ¿A quién corresponde esta decisión? ¿Qué papel juegan las madres en esta toma de decisiones? Antes de la tecnificación ¿las mujeres tenían voz en el proceso de atención a su maternidad?... A continuación Josefina Goberna justifica históricamente la poca e incluso nula voz que la mujer ha tenido a este respecto a lo largo de la historia. (Pág. 326 y ss).
} 
objetivos jurídicos exponer las causas de incapacitación. Aunque no se enumeran de forma taxativa, el artículo 200 CC indica: Son causas de incapacitación las enfermedades o deficiencias persistentes de carácter físico o psíquico que impidan a la persona gobernarse por sí misma. Sin adentrarnos en la introducción de una nueva figura tutelar -la curatela-, o la adscripción de órganos tuitivos de la persona al control judicial, el art. $200 \mathrm{CC}$ descarta per se el intento de incapacitar a una mujer por el mero hecho de querer ser madre a una edad que no suele ser la frecuente en nuestra sociedad.

Así, alegar por medio de la ética y la moral que las madres tardías no son capaces, deberá entenderse como una mera referencia al mayor o menor esfuerzo con el que estas habrán de atender los cuidados de sus hijos a partir de sus nacimientos y a lo largo de sus vidas: tanto la del hijo como la de la madre. Pero en ningún caso habrá de entenderse como la ausencia o minusvalía en su capacidad de obrar -jurídicamente hablando-.

No es necesario ser mujer y tener hijos para reconocer la evidencia natural de que la maternidad tiene periodos más óptimos que otros. Según un estudio científico británico ${ }^{45}$ publicado en la revista especializada "Health and Social Behavior", la mejor edad para ser madre no es a los 20 años -como popularmente se creía hasta hace poco tiempo-. Según una de las teorías más extendidas en la sociedad, la fertilidad de la mujer iría descendiendo a partir de los 25 años, cayendo de manera drástica a partir de los 35 . Sin embargo este estudio de origen británico asegura que la mejor edad para ser madre se sitúa entre los 34 y 35 años. Luego cabe reflexionar que la incapacidad natural o el esfuerzo añadido que la madre debe realizar para la crianza de un hijo a edades tardías, no solo lo hemos conceptualizado de manera errónea, sino que además tiene una carga psicológica muy fuerte, hasta ahora no tenida en cuenta. Carga psicológica que en especial las madres tardías -que previamente lo han sido en edades tempranas o medias-, asumen con total convencimiento y madurez, cimentando una fuerza que aumenta su capacidad maternal, al contrario de lo que inicialmente pudiera parecer. Nos convencemos cuando oímos que en numerosos tipos de cáncer, la fuerza y estabilidad psicológica son un

\footnotetext{
${ }^{45}$ Se llega a estas conclusiones tras analizar 3000 casos clínicos, tanto científicos como psicólogos.
} 
componente indispensable para su curación, e incluso para su mejor y más rápida cura. Sin embargo no se tiene en cuenta la fuerza psicológica que ha de tener una madre tardía para dar ese paso.

Ha sido muy mediático y debatido el asunto de la burgalesa de 64 años -M-I.A.- que dió a luz gemelos mediante cesárea programada, tras su sometimiento a fecundación in vitro en EEUU. A los tres años de dar a luz, murió. Seis años antes tuvo una hija -también por el método in vitro-, cuya custodia le fue retirada en 2014 por la Junta de Castilla y León, tras declararse la situación de desamparo. En este caso la Audiencia Provincial de Burgos declaró el desamparo y decretó la acogida de la niña, la cual se encuentra en custodia con un familiar de la madre. El aislamiento de la menor, su falta de higiene personal, la vestimenta inadecuada y el absentismo escolar, motivaron la sentencia judicial. Este caso no habría salido a debate público ni hubiera sido noticia, en el caso de que la madre no la hubiera tenido a edad avanzada. Sin embargo esta concreta cualidad de la madre -su edadha dado pie a sugerir la incapacidad de la madre, la cual a nuestro entender no tiene directamente relación alguna. La responsabilidad o irresponsabilidad de una persona no va indisolublemente fundida en relación a su edad.

Otra cuestión que pudiera plantearse -con independencia de la edad de la madre-, es la capacidad natural que ésta demuestra o no demuestra durante el desarrollo de su labor como un buen padre de familia ${ }^{46}$. En este caso la cuestión a analizar en todo caso, no sería la edad, sino la facultad poseída para tales fines -o no-, cuestión que hoy día no está regulada expresamente, pero cuya Jurisprudencia se ha ocupado de delimitar con la consecuente innecesaridad de regulación al respecto. A sensu contrario es digno analizar la inmadurez con la que muchas mujeres gestan a su primer hijo y sin embargo la sociedad no lo enjuicia ni valora ${ }^{47}$. Reconocer jurídicamente el matrimonio infantil -bajo el umbral

\footnotetext{
46 Término jurídico indeterminado expresado en la redacción del Código Civil, pero ampliamente referido y determinado por la Jurisprudencia española.

47 Según el Artículo 4 de la Convención de los Derechos de los Niños -CDN-, se exige a los Estados miembros que adopten todas las medidas legislativas, administrativas y demás para dar efectividad a los derechos reconocidos en él. Según un estudio de UNICEF finalizado a finales de enero de 2015, el 8\% de las niñas con edad inferior a los 15 años, se casan en América Latina y el Caribe -ALC-. Las normas
} 
de los 18 años-, implica el consentimiento de las niñas para tal fin, con la consecuente situación potencial de ser madres en estos periodos tan tempranos. Ello nos hace reflexionar sobre la siguiente cuestión: ¿es proporcional regular la edad para ser madre pasados los 50 -por ejemplo-, cuando se permite hoy día casar a las niñas con 12 años en algunos países?

b) Ante la consideración de madre irresponsable y carente de sentido común, habremos igualmente que tener en cuenta el término jurídico indeterminado al que nos referimos. Volveremos a preguntarnos si es más irresponsable tener un hijo a los 63 años que a los 12. La respuesta - originada desde el sentido común, la ética personal y la propia naturaleza humana- ha de concluir que una niña a los 12 años no puede ser considerada responsable de sus propios actos, y sin embargo una mujer de 63 años puede serlo totalmente. Esta capacidad o falta de capacidad respecto a la responsabilidad sobre los propios actos, no es comparable en ningún caso. Máxime cuando el caso de las madres tardías conlleva consigo un proceso previo de preparación y planificación del embarazo con conocimiento absoluto de las consecuencias del mismo. Si con doce años una niña no es responsable natural ni jurídicamente de sus actos,...¿Cómo va a ser del cuidado de un hijo? Una mujer de 65 años no vemos porqué no.

c) Cuando se utiliza como herramienta de ataque el futuro del hijo nacido para ofrecer peso y consistencia a la justificación del rechazo y la exposición pública de los deseos más íntimos de la mujer -especialmente en los intentos por ser madre a edades tasadas como tardías-, los juristas habremos de evitar jurídicamente este conflicto, al menos desde el prisma de nuestro propio ordenamiento jurídico. Es cierto que ser jurista no implica la necesaria unificación de ética y moral en las personas que formamos este

internacionales reconocen que la libertad al matrimonio, implica el consentimiento de los cónyuges. En Ecuador y en Trinidad Tobago -por ejemplo-, la edad mínima o más baja que se menciona en sus legislaciones es de 12 años, a pesar de que en la actualidad existe un proceso de reforma al respecto. Brasil, Costa Rica, República Dominicana, Nicaragua, Guyana y Santa Lucía permite el matrimonio entre los 14 y 16 años si hay consentimiento de los padres.

Sociedades como la árabe....permite el matrimonio a los tan solo X años de edad en las mujeres -niñas-, con las consecuentes maternidades tempranas -incapacidad física psicológica de la madre-, especialmente por su corta edad. Sin embargo se permite jurídicamente y éticamente no está mal visto. 
gremio. Pero todos habremos de respetar las normas existentes, por lo que hemos de concluir que al ser todas la personas iguales ante la ley ${ }^{48}$ y haciendo referencia de nuevo el Preámbulo de la LO 2/2010, de 3 de marzo, de salud sexual y reproductiva y de la interrupción voluntaria del embarazo: La protección de este ámbito de autonomía personal -el desarrollo de la sexualidad y la capacidad de procreación- tiene una singular significación para las mujeres, para quienes el embarazo y la maternidad son hechos que afectan profundamente a sus vidas en todos los sentidos. La especial relación de los derechos de las mujeres con la protección de la salud sexual y reproductiva ha sido puesta de manifiesto por los distintos textos internacionales. Así, en el ámbito de Naciones Unidas, la Convención sobre la eliminación de todas las formas de discriminación sobre la Mujer, adoptada por la Asamblea General mediante Resolución 34/180, de 18 de diciembre de 1979, establece en su artículo 12 que "Los estados Partes adoptarán las medidas apropiadas para eliminar la discriminación contra la mujer en la esfera de la atención médica a fin de asegurar, en condiciones de igualdad entre hombres y mujeres, el acceso a servicios de atención médica, incluidos los que se refieren a la planificación familiar”.... Es evidente la gran protección jurídica que tiene la capacidad de procreación tanto en el ámbito nacional como internacional, y que no ha de verse enfrentada -en todo caso- con los derechos de los hijos nacidos en madres tardías. Cuestiones que aunque paralelas junto a otras, habrán de ser analizadas de manera independiente.

Se ha utilizado el argumento del hijo menor de edad cuya madre tardía muere, con el consecuente desamparo del mismo, para amenazar -en algunos foros jurídicos-, acerca de tal pretensión. Conflicto a toda luz inadmisible dado que paralelamente habría que tener en cuenta el mismo desenlace proviniendo sin embargo de circunstancias muy diferentes, que no crean conflicto social alguno. Caso de las muertes de madres con edades reconocidas como aceptadas socialmente que mueren por enfermedades, accidentes, violencia de género, etc. En definitiva niños y niñas menores de edad que quedan en

\footnotetext{
48 “Derechos y libertades". Artículo 14 CE: Los españoles son iguales ante la ley, sin que pueda prevalecer discriminación alguna por razón de nacimiento, raza, sexo, religión, opinión o cualquier otra condición o circunstancia personal o social.
} 
desamparo socio-familiar, los cuales habrán de ser protegidos por unas normas jurídicas que procuren su correcto desarrollo a todos los niveles como persona y ofrezca soluciones a los problemas que puedan generarse en estas situaciones.

A la pregunta si la ciudanía tiene derecho a plantear la prohibición de la maternidad tardía, la respuesta se basa en equidad cuando afirmamos que de la misma manera que no se reconoce el derecho a la maternidad -como tal-, por ende no se puede reconocer el derecho a prohibirla. Todo lo más puede equipararse la voluntad de la mujer -su posibilidad de elección sobre este asunto-, con la voluntad o el interés de la sociedad para que esta situación sea regulada. Pero no existe un derecho al que aludir para este específico fin.

Si el artículo 3 de la L 14/2006, de 26 de mayo, especifica las condiciones personales de la aplicación de esta técnica, su artículo $6^{49}$, regula los usuarios de la misma. Es decir las mujeres receptoras en las técnicas de reproducción asistida: nuestras protagonistas. Así concreta que podrá ser receptora cualquier mujer mayor de 18 años, con capacidad de obrar y cuyo consentimiento haya sido prestado de manera escrita, libre, consciente y expresamente. ¿Hay alguna otra forma mediante la cual se adquiera fehacientemente mayor responsabilidad? ¿Cómo podremos tildar de irresponsables -en el ámbito jurídico, a las madres tardías? ¿Qué normativa avalaría esta irresponsabilidad por el hecho de tener más o menos edad? ¿Cuál sería el fin último de una posible regulación normativa? ¿Destruiríamos derechos, libertades o posibilidades éticamente lícitas y aceptadas por nuestra sociedad? ¿Cuál debe ser la atención que habremos de procurar a las redes sociales y mediáticas para plantear regulaciones jurídicas promovidas por supuestos movimientos sociales que pueden ser promovidos con fines tipificados como estafa ${ }^{50}$, para el convencimiento de una red plural y multitudinaria de pensamiento? ¿Tenemos los juristas un nuevo campo de actuación en la búsqueda de tiempo para la reflexión? Cuidado con la toma de decisiones en pro de la masa social y los círculos de opinión

\footnotetext{
${ }^{49}$ El art. 6 de la Ley 14/2006, de 26 de mayo, trata sobre los usuarios de las técnicas.

${ }^{50}$ Es el reciente ejemplo de lo ocurrido en la red Twitter respecto a los miles de tuits masivamente enviados desde perfiles de personas inexistentes en apoyo a la causa independentista de Cataluña.
} 
directa, cuando las nuevas tecnologías son manipulables con tanta facilidad, pudiendo provocar grandes desagravios jurídicos en la sociedad actual.

\section{BIBLIOGRAFÍA}

- S.Chopra, A. Lotvin, D. Fisher. El Doctor Chopra dice: hechos médicos y mitos que todos deberíamos conocer. Penguin Random House Grupo. Editorial España, 25 abril 2012- 488 páginas.

- M.Boladeras, ed. Bioética: la toma de decisiones. Editorial Proteus. Primera edición: Octubre 2011. 619 páginas.

WEBGRAFÍA (consultas: septiembre, octubre y noviembre 2017)

- https://es.wikipedia.org/wiki/Alois_Alzheimer

- https://www.tuftsctsi.org/people/steven-c-vlad/

- http://www.alzheimergranada.com/files/cm157228/descargas/file-2015-1127 083028-3.pdf

- https://es.wikipedia.org/wiki/Embarazo_humano

- http://www.who.int/es/

- $\quad$ http://digibuo.uniovi.es/dspace/bitstream/10651/18002/7/TFM\%20Casta\%C3\% B10\%20Hernandez\%2C\%20Mariel.pdf

- http://andaluciainformacion.es/sevilla/683808/alumnos-del-marie-curie-recibenlas-clases-en-el-pasillo-por-el-calor/

- http://www.cuatro.com/cronicacuatro/etico-mama-sesenta-HoyCronica 2 2324730094.html

- http://www.codigoeticoabogadas.es/es/noticias-detalle/derecho-al-honor-versuslibertad-de-expresion/ 
- https://politica.elpais.com/politica/2017/03/13/actualidad/1489432658_991583.h $\underline{\mathrm{tml}}$

- $\quad$ http://www.eldiario.es/sociedad/desamparo-huerfanos-violencia-machistaolvidado_0 626787684.html

- http://www.lealtadis.es/relevante-sentencia-concede-pension-orfandad-la-hijauna-victima-violencia-genero/

- https://eresmama.com/cuales-las-causas-reales-la-maternidad-tardia/

- $\quad$ http://www.amic.media/media/files/file 352 1050.pdf

- $\quad$ http://www.elmundo.es/salud/2017/02/15/58a438cbca474181468b45fb.html

- https://smoda.elpais.com/belleza/bienestar/edad-puedo-madre/

- http://www.enfemenino.com/embarazo/mejor-edad-ser-madre-s2208860.html

- https://www.unicef.org/lac/20160406_UNICEF_Edades_Minima_Esp(1).pdf

- http://www.abc.es/espana/abci-julian-assange-colgo-40000-mensajes-twitterapoyando-secesionismo-catalan-201711120307 noticia.html 